ROCZNIKI FILOZOFICZNE

Volume LXVII, issue $4-2019$

DOI: https://dx.doi.org/10.18290/rf.2019.67.4-9

DAVID BURRELL, C.S.C.

\title{
GAVEN KERR, O.P., ON CREATION WITH ITS PHILOSOPHICAL COROLLARIES
}

Gaven Kerr, O.P., is rightfully known for his Aquinas's Way to God: The Proof in De Ente et Essentia (2015). I was moved to endorse this study, for the way it shows the centrality of Aquinas' metaphysics of creation: showcasing the 'real distinction' between esse and essentia, followed by Aquinas' unique treatment of each, as well as a deep consideration of esse tantum, all lead into the act of creation. By contrasting at each nodal point Aquinas with contemporary and classical alternatives, Aquinas has to face formidable critics and fares quite well. And Kerr culminates his study by highlighting free creation as the key to this metaphysical tour de force. So Aquinas' own perspectives are evident in the artful melding of 'philosophy' with 'theology,' as we would put it today.

The study could profit from an inter-cultural direction: showing how these very notions possess an articulate structure and a 'depth grammar' as Aquinas found them and re-fashioned them. That would help readers see how Aquinas managed to be so innovative, gleaning from ways Muslim and Jewish thinkers had developed these critical notions. For the author's clear presentation can read as though the key notions here were simply there for the asking. He would be advised to explore contextual and intercultural contexts at work (in Aquinas and in us), to help students appreciate Aquinas special talent for synthesis. Wider reading in his own tradition would also allow him to mine the 'apophatic' dimensions of esse-mentioned but hardly developed here. (Sara Grant's comparison of Aquinas with Shankara is quite suggestive.) In sum, there is more to be found in Aquinas than the "canonical' commentators he knows and uses so well can supply.

DAVID BurRelL, C.S.C. - Hesburgh Professor emeritus, University of Notre Dame, IN, USA; address for correspondence — e-mail: david.b.burrell.2.nd@gmail.com; ORCID: https://orcid.org/00000001-6117-386X. 
But let me add to this critical appreciation a note on the way the 'essence/existing' distinction tellingly embodies the central 'creator/creature' so dear to Robert Sokolowski. For the very activity of a being of any kind [essence] manifests the 'fact' of its existing, which bespeaks its participation in being as bestowed by its creator. So the 'proof' which Gaven Kerr has articulated so deftly reflects the manner in which the Creator 'appears' in creation, thereby 'showing' what cannot be 'said' (Wittgenstein).

\section{BIBLIOGRAPHY}

Grant, Sara. Toward an Alternative Theology: Confessions of a Non-Dualist Christian. Bangalore: Asian Trading Corporation, 1991.

Kerr, Gaven, O.P. Aquinas's Way to God: The Proof in De Ente et Essentia. Oxford University Press, 2015.

Sokolowski, Robert. God of Faith and Reason. Notre Dame, IN: University of Notre Dame Press, 1983; Washington, DC.: Catholic University of America Press, 1995.

\section{GAVEN KERR, O.P., ON CREATION WITH ITS PHILOSOPHICAL COROLLARIES}

\section{S u m m a ry}

Author endorses the study by Gaven Kerr, O.P., for the way it shows the centrality of Aquinas' metaphysics of creation: showcasing the 'real distinction' between esse and essentia, followed by Aquinas' unique treatment of each, as well as a deep consideration of esse tantum. At the end he states the 'proof' which Gaven Kerr has articulated so deftly reflects the manner in which the Creator 'appears' in creation, thereby 'showing' what cannot be 'said' (Wittgenstein).

\section{GAVEN KERR OP O STWORZENIU I JEGO KONSEKWENCJACH FILOZOFICZNYCH}

$$
\text { Streszczenie }
$$

Autor z przekonaniem pochwala studium Gavena Kerra OP za sposób, w jaki pokazuje ono centralność metafizyki stworzenia u Akwinaty: ukazanie „realnej różnicy” między esse i essentia, a następnie unikatowe potraktowanie każdego z nich, jak też głębokie rozważenie esse tantum. Na koniec stwierdza, że „dowód”, który sformułował Gaven Kerr, zręcznie odzwierciedla sposób, w jaki Stwórca „pojawia się” w stworzeniu, a tym samym „pokazuje” to, czego nie da się powiedzieć (Wittgenstein).

\section{Przełożyt Stanisław Sarek}

Key words: Aquinas' metaphysics of creation; esse; essentia; esse tantum.

Slowa kluczowe: Akwinaty metafizyka stworzenia; esse; essentia; esse tantum.

Informacje o Autorze: DAVID BURRELL, CSC - emerytowany profesor University of Notre Dame, IN, USA; adres do korespondencji — e-mail: david.b.burrell.2.nd@gmail.com; ORCID 0000-00016117-386X. 